\title{
CHARACTERISTICS OF TWO FULL-DEPTH SLAB AVALANCHES ON MEALL UAINE, GLEN SHEE, SCOTLAND
}

\author{
By Richard William Davison and Steven Keith Davison \\ (9 Berrydale Road, Blairgowrie, Perthshire PH10 6UA, Scotland)
}

ABSTRACT. The characteristics of two full-depth slab avalanches that occurred in 1982 and 1984 at the same location on Meall Uaine in Glen Shee, Scotland, are described. Notable features include the relatively low altitude of the site $(c .670 \mathrm{~m})$ compared to sites of other avalanches observed elsewhere in Scotland, the depth of snow involved (up to $4 \mathrm{~m}$ ), a snow-pack similar to those recorded in the Cairngorm Mountains, and the entrainment, transport, and deposition of boulders and turf. The probability of the two avalanches occurring when they did was greater than $60 \%$. It is suggested that further observations of full-depth slab avalanches might be obtained by identifying terrain similar to that of the site studied here.

\section{INTRODUCTION}

In Scotland, only three full-depth avalanches have been recorded definitely (Ward, 1984[a]), so our knowledge of this type of avalanche is very limited. The main aim of this note is to present data on two full-depth slab avalanches that occurred on 30 December 1982 and 11 April 1984 at the same location on Meall Uaine in Glen Shee, Scotland. Studies by King (unpublished), Shaw (unpublished), and Ward (unpublished) of the geomorphological effect of avalanches in corries and on slopes at high altitudes in Scotland have been inconclusive owing to the absence of direct evidence. The second aim, therefore, is to outline the geomorphic effect of the two avalanches under study. The third aim is to assess the validity of a method, developed by Ward (unpublished), for forecasting avalanches in Scotland.

\section{THE SITE}

The location of the site (lat. $56^{\circ} 47^{\prime} \mathrm{N}$., long. $3^{\circ} 27^{\prime} \mathrm{W}$.) is illustrated in Figure 1. The site lies at an altitude of approximately $670 \mathrm{~m}$ in the south-east-facing basin of Meall Uaine. The slope, which is unconfined, is convex in shape at the line of fracture but concave below this point. In the release zone, the slope has an average angle of $33^{\circ}$ and a maximum angle of $35^{\circ}$ (measurements made with an Abney level). The vegetation, comprising crowberry (Empetrum sp.), bilberry (Vaccinium myrtillus), cowberry (Vaccinium vitisidaea) and, to a lesser extent, heather (Calluna vulgaris) and Nardus grass (Nardus stricta), reaches a maximum height of approximately $0.15 \mathrm{~m}$. A few boulders are located on the slope. The nearest official weather station (Fig. 1) is at Kindrogan (lat. $56^{\circ} 45^{\prime} \mathrm{N}$., long. $3^{\circ} 33^{\prime} \mathrm{W}$.), $7 \mathrm{~km}$ to the south-west at an altitude of $259 \mathrm{~m}$ (i.e. $411 \mathrm{~m}$ below the altitude of the site).

\section{OBSERVATIONS}

Avalanche characteristics

Figure 1 provides a plan view of the avalanche site and Figures 2 and 3 provide data, recorded at Kindrogan,

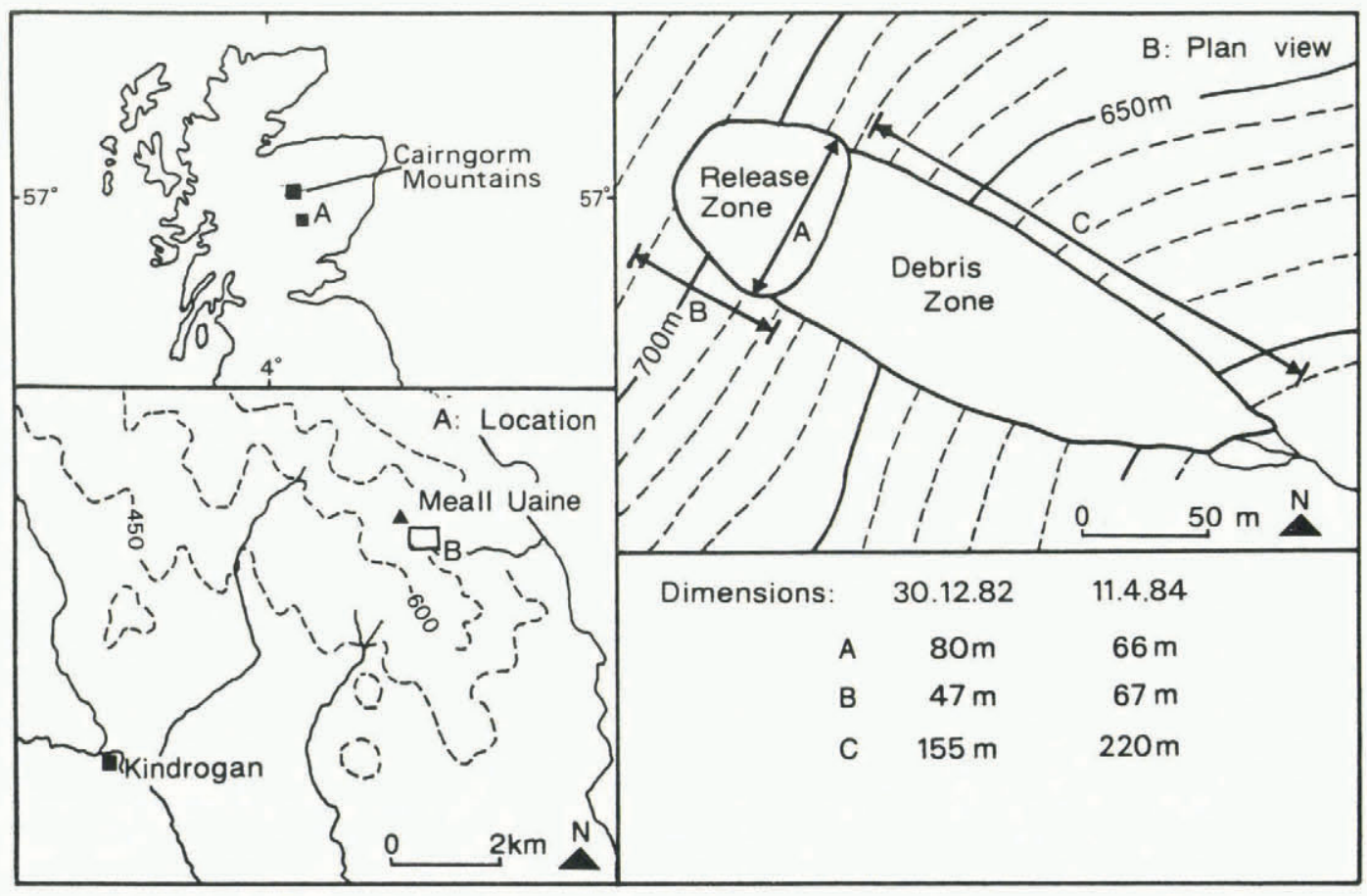

Fig. I. Location map and plan view of the avalanche site. 


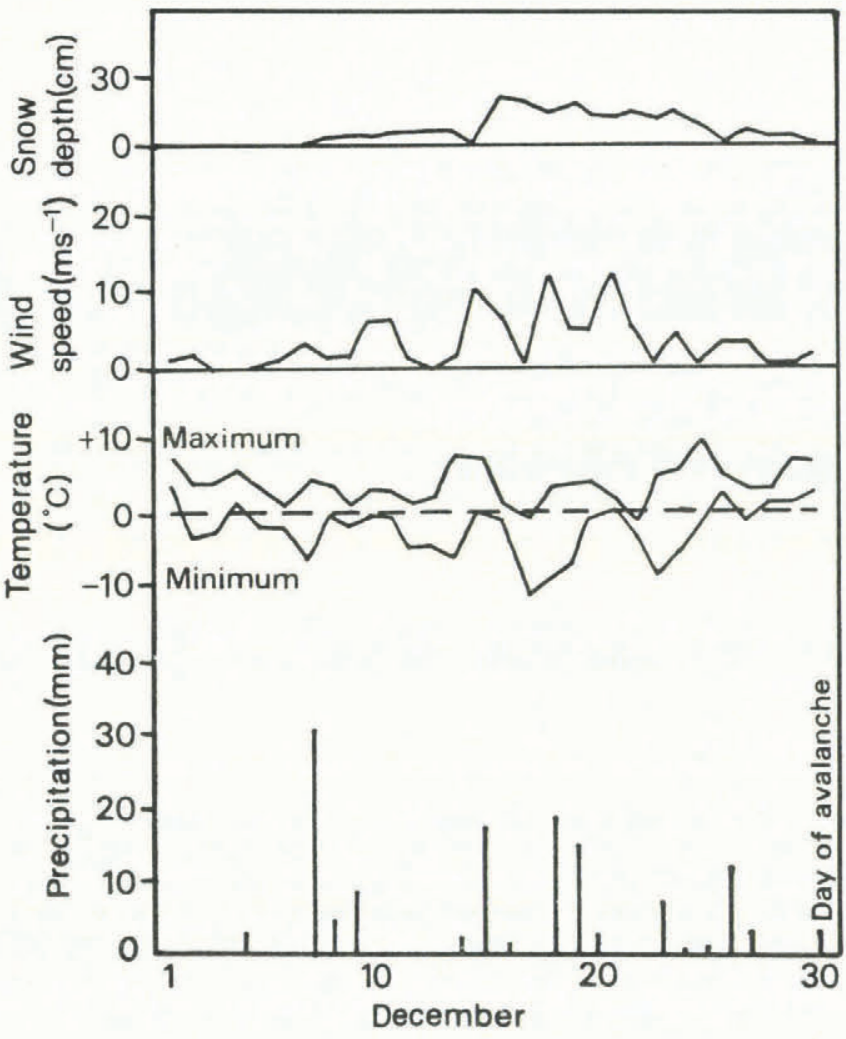

Fig. 2. Precipitation, temperature, snow depth, and wind speed recorded at Kindrogan $(259 \mathrm{~m})$ from 1 December 1982 to the avalanche date (30 December 1982).

on wind speed, precipitation, snow depth, and temperature for December 1982 and for January to 11 April 1984, respectively.

December 1982 was noted for heavy precipitation, falling mostly as snow above c. $600 \mathrm{~m}$, associated with strong winds from the west-south-west and west-north-west (Davison, 1986). Substantial depths of snow, therefore, accumulated on south-east-facing slopes. After 26 December 1982, there was a sharp thaw with maximum air temperatures reaching $7^{\circ} \mathrm{C}$ at Kindrogan. In 1984, January and late March were noted for heavy snowfall (Fig. 3); we noted that, above $c$. $600 \mathrm{~m}$, snow accumulated to unusual depths on east-facing slopes. Maximum air temperatures at $\mathrm{K}$ indrogan, although variable, rose to $10^{\circ} \mathrm{C}$ after the snowfalls in late March. The classification of the two avalanches is listed in Table I. All dimensions, except the total length of the debris zone (estimated), were measured on site.

TABLE I. CHARACTERISTICS OF THE TWO AVALANCHES, ACCORDING TO THE CLASSIFICATION OF DE QUERVAIN AND OTHERS (1973)
Fracture type

Fracture depth

Liquid water content

Degree of confinement

Deposits

Contamination

Maximum depth of snow

At line of fracture

Wall of release zone
Type of motion
Slab

Full depth

High (wet)

On the ground

Open

Angular blocks

Rock, soil

30 Dec 1982

11 Apr 1984

$0.25 \mathrm{~m}$

$2.00 \mathrm{~m}$

$1.00 \mathrm{~m}$

$4.00 \mathrm{~m}$
Some characteristics of the snow-pack at the fracture line of the 11 April 1984 avalanche (the first avalanche sparked our interest so, at that time, we were not prepared for taking measurements) are illustrated in Figure 4 . The main features of the snow-pack were: (1) wet, soft snow; (2) grain diameters of between 2 and $4 \mathrm{~mm}$; (3) three ice layers; and (4) slush at ground level. The relatively homogeneous stratigraphy, together with ice layers and quite large grain-sizes, suggests that the snow-pack may be a product of several heavy snowfalls, e.g. those in January and late March, interspersed by short periods of thaw (see Fig. 3).

This snow-pack is similar, therefore, to those described by Ward (1985) at locations in the Cairngorm Mountains (30 km to the north-west; see Fig. 1). Of particular similarity are the grain-sizes, the stratigraphy, the existence of ice and slush, and the values of hardness and wetness. Whether this snow-pack is unique for the Glen Shee area is not known; previous studies of the characteristics of snow-

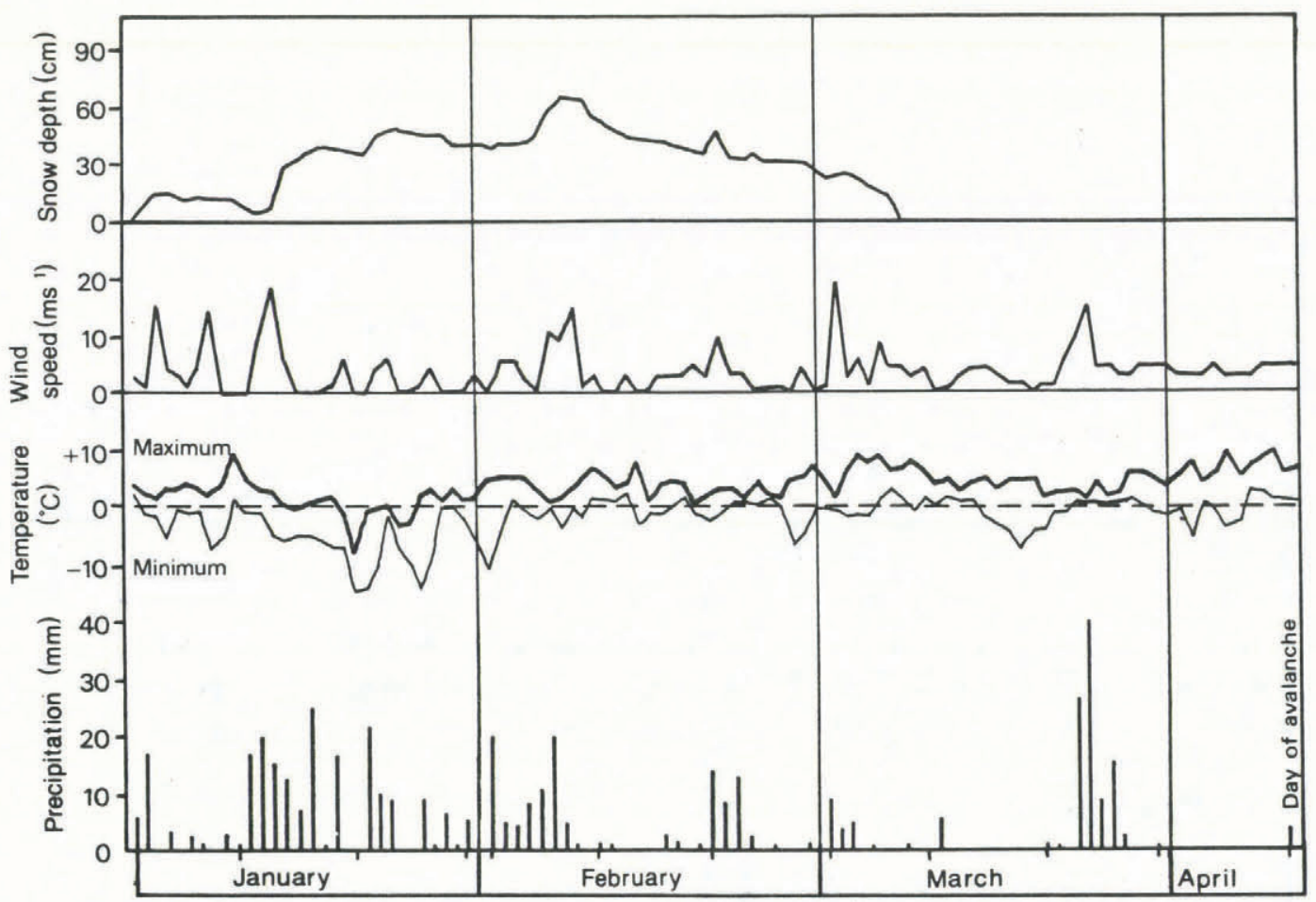

Fig. 3. Precipitation, temperature, snow depth, and wind speed recorded at Kindrogan (259 $\mathrm{m}$ ) from $\mathrm{l}$ January 1984 to the avalanche date (11 April 1984). 

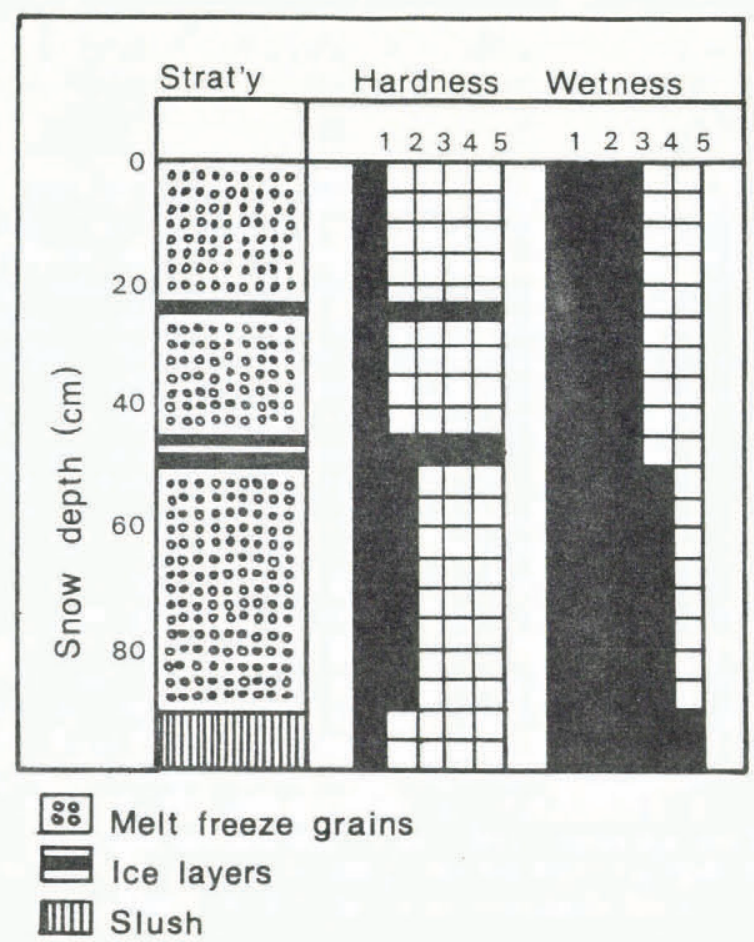

Fig. 4. Characteristics of the snow-pack measured at the fracture line of the 11 April 1984 avalanche. Hardness: 1, fist in; 2, hand in; 3, finger in; 4, pencil in; 5, knife in (Ward, 1985). Wetness: 1, no snowball; 2, snowballs formed in hand; 3, hand damp; 4, water squeezed; 5, slush (Ward, 1985).

packs in Scotland have been restricted to sites in the Cairngorm Mountains.

\section{Geomorphological effects}

During observation of both avalanches, we noted soil entrained within the snow, so we surveyed the site in the summers of 1983 and 1984 to determine the geomorphological effects of the two avalanches. The main effects were the movement of boulders down-slope and the uprooting of turf. Detailed effects are listed below.

(1) The 30 December 1982 avalanche moved a boulder $(1 \mathrm{~m} \times 1 \mathrm{~m} \times 0.5 \mathrm{~m})$ down-slope for $1.10 \mathrm{~m}$ within the debris zone, thus creating a ruffle of turf (height $0.35 \mathrm{~m}$ ) at the front of the boulder. A section of turf $(2 \mathrm{~m} \times 1.30 \mathrm{~m})$ was uprooted and moved down-slope for $3 \mathrm{~m}$ within the release zone.

(2) The 11 April 1984 avalanche moved a boulder $(2 \mathrm{~m} \times 1.5 \mathrm{~m} \times 0.5 \mathrm{~m})$ down-slope for approximately $150 \mathrm{~m}$ from the release zone. Many smaller boulders were similarly moved. Several pieces of turf, one $5 \mathrm{~m}$ in length, were uprooted and moved down-slope.

Although small in scale compared to the effects recorded in other countries, the observations confirm that avalanches in Scotland do entrain, transport, and deposit material on slopes, as shown in Canada (Luckman, 1978; Gardner, 1983) and Norway (Rapp, 1960). Whether these effects will have longer-term consequences, e.g. small-scale erosion, is not known.

\section{PROBABILITY OF OCCURRENCE}

From a study of 98 days on which avalanches have occurred in the Cairngorm Mountains, Ward (1984[b], unpublished) developed statistical surfaces on which a particular day has a certain probability that avalanches would occur, according to the amount of new snowfall and temperatures experienced. Ward intended that the probability surfaces be used as a "tool" for forecasting avalanches; the aim here is to see how valid this tool might be for fulldepth slab avalanches in an area outside the Cairngorm Mountains. It is hoped that by using the model the occurrence of the two avalanches may be accounted for.

The model makes a number of assumptions on input data; these are listed below.

(1) That snow-packs similar to those in the Cairngorm Mountains exist; limited evidence presented earlier suggests that this may be satisfied.

(2) That on-site temperature data are available by applying lapse rates to low-altitude data (in this case from Kindrogan). Lapse rates of 6 deg per $1000 \mathrm{~m}$ for December and 8 deg for April (Barry, 1981) were applied for this exercise.

(3) That data on actual depth of snowfall are available (no assumption was made by Ward (unpublished) on altitudinal increases in snowfall). As only waterequivalent data are available, conversions must be made according to the density of newly fallen snow. Although Ward (unpublished) employed a density of $0.1 \mathrm{Mg} \mathrm{m}^{-3}$ for these conversions, using the value invalidates the data available for the second avalanche as the amount of snowfall far exceeded those used by Ward (unpublished) to develop the model. Ferguson (1985) found the density of "fresh-looking powder snow" in the Cairngorm Mountains to be $0.27 \mathrm{Mg} \mathrm{m}^{-3}$. This value, therefore, is used here, though it is recognized that this will underestimate the resultant probability.

Table II lists the data required. In terms of mean maximum temperature during the preceding thaw and the

TABLE II. METEOROLOGICAL CONDITIONS PRECEDING EACH AVALANCHE. SNOWFALL IS DERIVED FROM WATER-EQUIVALENT VALUES AT KINDROGAN AND CONVERTED TO DEPTH USING A DENSITY OF $0.27 \mathrm{Mg} \mathrm{m}^{-3}$. TEMPERATURES ARE ON-SITE ESTIMATES DERIVED FROM OBSERVATIONS AT KINDROGAN

30 Dec 198211 Apr 1984

$\begin{array}{lcc}\text { Last snowstorm: date } & 26.12 .82 & 23 / 26.3 .8 \\ \text { snowfall } & 44 \mathrm{~mm} & 336 \mathrm{~m} \\ \begin{array}{l}\text { Number of thaw days since } \\ \text { snowstorm }\end{array} & 4 & 15 \\ \begin{array}{l}\text { Mean maximum temperature } \\ \text { since snowstorm }\end{array} & +2.7^{\circ} \mathrm{C} & +3.8^{\circ} \mathrm{C} \\ \begin{array}{l}\text { Maximum temperature on } \\ \text { day of release }\end{array} & +4.6^{\circ} \mathrm{C} & +3.8^{\circ} \mathrm{C}\end{array}$

maximum temperature on the day of release (Fig. 5), there was a probability of between $60 \%$ and $70 \%$ that the avalanches would occur on the day that they did. The rise in probability, based on snowfall in the last storm and the number of thaw days (i.e. days with a maximum air temperature of $>0{ }^{\circ} \mathrm{C}$ recorded in the $24 \mathrm{~h}$ after $09.00 \mathrm{~h}$ ), before the second avalanche, is plotted in Figure 6. Between 3 and 5 April, the probability rose from below $40 \%$ to above $70 \%$, though the avalanche did not occur for a further 6 days.

The method appears quite accurate in determining the probability of the avalanches occurring on the days that they did, though more data are required to test the model further. Both avalanches appear to have been the product of thaws, though the first was probably the result of a sharp, but brief, thaw and the second probably arose from a prolonged thaw. The presence of slush at ground level in the snow-pack of the second avalanche (Fig. 4) suggests that this may have acted as a lubricant to the snow.

\section{DISCUSSION}

The scale and effect of the two avalanches may appear small in an international context but, in a Scottish context, the observations are important. Compared with avalanches 


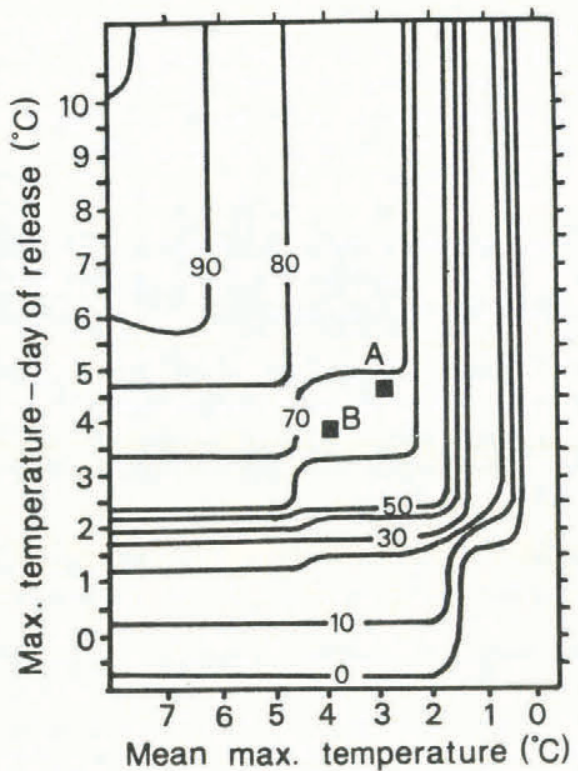

Fig. 5. Avalanche probability as a function of mean maximum temperature during $a$ thaw and maximum temperature on the day of release (Ward, 1984[b]). A, 30 December 1982; B, 11 April 1984. (Reproduced with permission of Butterworth Scientific Ltd and R.G.W. Ward.)
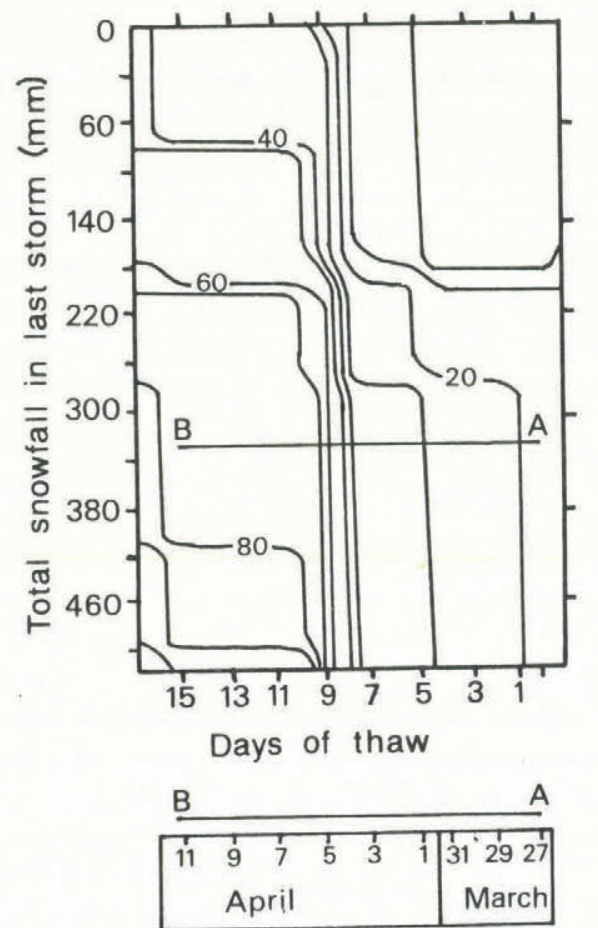

Fig. 6. Plot (A---B) of rise in probability of second avalanche (11 April 1984) as a function of total snowfall in last storm and number of days of thaw (Ward, 1984[b]). (Reproduced with permission of Butterworth Scientific Ltd and R.G.W. Ward.)

(usually surface slabs or sloughs) recorded by Ward and others (summarized by Ward (1984[a])), the two avalanches were of average size. The depths of snow involved, however, were above average, despite the relatively low altitude of the site. The slope angle is below average; Ward (1984[a]) reported that only about $16 \%$ of all avalanches recorded in Scotland occurred on slopes of less than $35^{\circ}$. Avalanches, of any type, on south-eastern slopes are uncommon, particularly in areas outside the Cairngorm Mountains (Ward, 1984[a]). The two avalanches, therefore, appear to be unusual, though the deep drifts, low altitude, and south-east aspect would all seem to encourage the occurrence of avalanches. These points raise the question of just how frequent full-depth slab avalanches are in Scotland.

Most avalanches have been recorded in high corries or on high slopes (usually above $900 \mathrm{~m}$; Ward, 1984[a]) of mountains visited frequently by hill-walkers and skiers. Virtually all of the avalanches recorded at these locations are either sloughs or surface slabs, so it is possible that many full-depth slab avalanches go unrecorded simply because they most probably occur on mountains of relatively low altitude with smooth vegetated slopes, that are not visited frequently by hill-walkers or skiers. There is an opposing argument, however, in that the site studied here appears to have a high "threshold", i.e. avalanches occur only when the probability is high $(360 \%)$. This may mean that full-depth avalanches, at this site at least, occur only when the probability is high and are therefore rare. The obvious solution is to improve observation techniques.

One way of achieving this would be to identify areas of similar altitude and terrain in Scotland. By identifying similar terrain in a certain area, a "population" of sites where full-depth slab avalanches may be quite frequent can be established. Avalanche observations could then be obtained more easily by concentrating on these sites. Bayfield and others (1982) have classified the terrain of the Glen Shee area and the Cairngorm Mountains, and this may provide a useful starting point for such an exercise.

\section{REFERENCES}

Barry, R.G. 1981. Mountain weather and climate. London and New York, Methuen.

Bayfield, N.G., and others. 1982. An indicator species analysis of map squares and vegetation in the Cairngorms, by N.G. Bayfield, M.G. Penny, and S.M. Moyes. Transactions of the Botanical Society of Edinburgh, Vol. 44 , p. $35-47$.

Davison, R.W. 1986. Winter weather and the supply of snow in the eastern Highlands of Scotland: 1954/5 to $1983 / 4$. Edinburgh, University of Edinburgh. Department of Geography. (Research Discussion Paper 21.)

Ferguson, R.I. 1985. High densities, water equivalents, and melt rates of snow in the Cairngorm Mountains, Scotland. Weather, Vol. 40, No. 9, p. 272-77.

Gardner, J.S. 1983. Observations on erosion by wet snow avalanches, Mount Rae area, Alberta, Canada. Arctic and Alpine Research, Vol. 15, No. 2, p. 271-74.

King, R.B. Unpublished. Periglacial features in the Cairngorm Mountains. [Ph.D. thesis, University of Edinburgh, 1968.]

Luckman, B.H. 1978. Geomorphic work of snow avalanches in the Canadian Rocky Mountains. Arctic and Alpine Research, Vol. 10, No. 2, p. 261-76.

Quervain, M. de, and others. 1973. Proposal of the Working Group on Avalanche Classification of the International Commission on Snow and Ice, by M. de Quervain, L. de Crécy, E.R. LaChapelle, K. Losev, and M. Shoda. Hydrological Sciences Bulletin, Vol. 18, p. 391-402.

Rapp, A. 1960. Recent development of mountain slopes in Kärkevagge and surroundings, north Scandinavia. Geografiska Annaler, Vol. 42, Nos. 2-3, p. 65-200.

Shaw, R. Unpublished. Periglacial features in part of the south east Grampian Highlands of Scotland. [Ph.D. thesis, University of Edinburgh, 1977.]

Ward, R.G.W. 1984[a]. Avalanche prediction in Scotland: I. A survey of avalanche activity. Applied Geography, Vol. 4, p. $91-108$.

Ward, R.G.W. 1984[b]. Avalanche prediction in Scotland: II. Development of a predictive model. Applied Geography, Vol. 4, p. 109-33.

Ward, R.G.W. Unpublished. Snow avalanches in Scotland with particular reference to the Cairngorm Mountains. [Ph.D. thesis, University of Aberdeen, 1981.]

Ward, R.G.W., and others. 1985. Snow profiles and avalanche activity in the Cairngorm Mountains, Scotland, by R.G.W. Ward, E.D.G. Langmuir, and B. Beattie. Journal of Glaciology, Vol. 31, No. 107, p. 18-27. 